\title{
Production rates of volatile fatty acids in the minke whale (Balaenoptera acutorostrata) forestomach
}

\author{
BY MONICA ALTERSKJÆR OLSEN* AND SVEIN DISCH MATHIESEN \\ Department of Arctic Biology and Institute of Medical Biology, University of Tromso, \\ N-9037 Tromsø, Norway
}

(Received 24 October 1994 - Revised 28 March 1995 - Accepted 3 May 1995)

\begin{abstract}
Minke whales (Balaenoptera acutorostrata) have developed a compartmentalized stomach system, which includes a non-glandular forestomach containing high concentrations of indigenous bacteria. The forestomach contents serve as microbial substrate, and samples were collected from five adult minke whales eating capelin (Mallotus villosus) and crustaceans (Thysanoessa sp.). Chemical analysis of the forestomach contents revealed that they consisted of crude protein (650 (SD 58) $\mathrm{g} / \mathrm{kg} \mathrm{DM}$ ), lipid (330 (SD 77) $\mathrm{g} / \mathrm{kg} \mathrm{DM}$ ) and water-soluble carbohydrates (53.3 (SD 7.3) $\mathrm{g} / \mathrm{kg} \mathrm{DM}$ ). The contribution of energy from volatile fatty acids (VFA), produced by forestomach bacterial fermentation, to the total energy budget was estimated. The forestomach concentration of VFA ranged from 13.2 to $68.5 \mathrm{mmol} / \mathrm{l}$, and the pH was 5.83 (SD 0.41). VFA pool size ranged from 72.8 to $638.1 \mathrm{mmol}$ and represented from 0.169 to $2 \cdot 107 \mathrm{~kJ} / \mathrm{kg}$ live weight $(\mathrm{W})^{0.75}$. Maximal recorded forestomach VFA production rate was $1694 \mathrm{mmol} / \mathrm{h}$ in one capelin-eating minke whale with $\mathbf{4 2 . 6}$ litres of forestomach fluid. Energy from VFA produced by forestomach fermentation represented $6-107 \mathrm{~kJ} / \mathrm{kg} \mathrm{W} \mathrm{W}^{0.75}$ per $\mathrm{d}$, which accounts for only $0.9-16.9 \%$ of the average daily energy expenditure of minke whales. This study suggests that the bacterial fermentation in the minke whale forestomach varies, depending on the volume and the quality of substrate available, influencing fermentation rates and concentration of VFA. Due to the small relative size of the forestomach, the contribution of VFA to the daily energy requirement in minke whales would be of less importance than in ruminants even when assuming the same production rate of VFA as in a ruminant.
\end{abstract}

Volatile fatty acids: Minke whale: Forestomach

Minke whales are small baleen whales feeding on crustaceans and different fish species (Nordøy \& Blix, 1992; Haug et al. 1995). The prey is digested in a multichambered stomach system which includes a non-glandular forestomach, resembling that of ruminants (Olsen et al. $1994 \mathrm{~b}$; Mathiesen et al. 1995). The stomach is followed by a relatively short intestine, and the compartmentalization of the stomach is therefore thought to aid in the retention of food, and hence increase the passage time through the gastrointestinal (GI) tract (Olsen et al. 1994b; Mathiesen et al. 1995). The stomach is small, comprising only $27 \%$ of the total tissue wet weight of the GI system (Olsen et al. 1994b), compared with domestic ruminants like the sheep (49\%; Wardrop \& Coombe, 1960). The significance of the forestomach fermentation in minke whales is discussed in comparison with data from ruminants, since no such data are available from whales. In ruminants, which rely on bacteria to digest cellulose, the volatile fatty acids (VFA) diffuse across the rumen wall (Stevens, 1973), and as much as $70 \%$ of the ingested metabolizable energy passes through the rumen VFA pool (Annison \& Armstrong, 1970). High concentrations of VFA have been found in the 
forestomachs of large baleen whales, like grey (Escherichtius robustus), bowhead (Balaena mysticetus) and fin (Balaenoptera physalus) whales, in which maximal concentrations of $558(n 4), 1060(n 7)$ and $247(n 16) \mathrm{mmol} / 1$ respectively were found (Herwig et al. 1984; Herwig \& Staley, 1986). Investigations of the forestomach microbiology of large baleen whales are influenced by the difficulties in obtaining fresh samples. High numbers of anaerobic bacteria have been observed in the minke whale forestomach (Olsen et al. 1994a). Studies by Olsen et al. (1994a) indicate that the dominating bacterial population is indigenous to the forestomach, and scanning electron microscopic examinations have revealed that bacteria closely associate with the food particles. These findings support the hypothesis that the forestomach of minke whales not only has anatomical and histological but also functional similarities with the ruminant rumen. According to Nordøy et al. (1993) $70 \%$ of the DM disappears into solution after microbial degradation in the forestomach. Olsen et al. (1994a) suggest that the forestomach decomposition of foods like fish and crustaceans, which contain mostly proteins and lipids but also polysaccharides, occurs by bacterial attachment and degradation of the prey to produce bacterial protein and VFA. The contribution of fermentation products such as VFA to the daily energy supply is, however, still unknown. The forestomach fermentation in minke whales was evaluated by investigating production rates of VFA by the zero-time in vitro technique (Carroll \& Hungate, 1954; Hungate et al. 1961; Hungate, 1966).

\section{MATERIALS AND METHODS \\ Animals}

Samples were collected from a total of five female minke whales (5.98-7.64 m) (Haug $e t$ al. 1995) during the Norwegian scientific whaling in July and August 1992, under licence issued by the Norwegian government in accordance with Article VIII of the International Convention for Regulation of Whaling (Anonymous, 1950). Catches were carried out west of Spitsbergen $\left(78-79^{\circ} \mathrm{N}\right)$. A laboratory with incubators, freezers and necessary equipment was established on board the whaling vessel. The whale was killed and taken on board on the deck of the vessel. The body mass was estimated from body length (data from Haug et al. 1995), according to the method of Folkow \& Blix (1992).

\section{Blood sampling}

Blood was obtained by cutting the jugular vein or the carotid artery of the animal, using EDTA as anticoagulant; $10 \mathrm{ml}$ EDTA blood was fixed in $5 \mathrm{ml} 0.5 \mathrm{M}-\mathrm{HCl}$, and frozen $\left(-20^{\circ}\right)$.

\section{In vitro fermentation of forestomach contents}

When obtaining stomach contents, standard methods accepted for rumen microbiological studies were used (Orpin et al. 1985; Olsen et al. 1994a; Aagnes et al. 1995). The total GI tracts were removed immediately after the animals were killed, allowing incisions through the forestomach wall for sampling of contents (Olsen et al. 1994a) within 62-91 min of death. To obtain the concentration and production rate of the main VFA, acetate, propionate and butyrate, a sub-sample (2-3.5 litres) of the forestomach content was incubated in a 5-litre plastic flask immediately sealed with a rubber stopper equipped with a one-way valve to ensure anaerobic conditions (Tilley \& Terry, 1963). The flasks were incubated in the dark at $35^{\circ}$ (Olsen et al. 1994a). The total volume of the forestomach contents was recorded, and the total forestomach fluid volume was calculated after determining the DM content. The zero-time in vitro technique (Carroll \& Hungate, 1954; Hungate et al. 1961; Hungate, 1966) was used to obtain the concentration and production 
rate of VFA in the forestomach fluid of minke whales. This method has also been used by other scientists (e.g. Stewart et al. 1958; Allo et al. 1973; Gasaway \& Coady, 1974; van Hoven et al. 1981; White \& Staaland, 1983). By incubating a sample of forestomach ingesta anaerobically, a curve could be constructed from the increase in VFA levels in the sample during the incubation period. The slope of the curve, which is determined mathematically, is assumed to be the rate of production in vivo at the time the sample was obtained from the animal. A total of six forestomach samples were collected from each anaerobic plastic flask at intervals of $15 \mathrm{~min}$ after the incubation had started. Precautions were taken to prevent $\mathrm{O}_{2}$ from entering the flasks. According to our experience gas is produced during the incubation, producing a pressure inside the flask that prevents $\mathrm{O}_{2}$ from entering. The forestomach content was mixed by shaking the flasks before each sampling, a sub-sample $(100-150 \mathrm{ml})$ was sieved through two layers of muslin, and $10 \mathrm{ml}$ of the filtrate was fixed in $5 \mathrm{ml} 0.5 \mathrm{M}-\mathrm{HCl}$ and frozen $\left(-20^{\circ}\right)$. By extrapolating the regression lines to zero the concentration of VFA at the time of death and the slope of the line that gives the production rate could be calculated. The pool size is known from the product of the concentration of VFA and the forestomach fluid volume. By multiplying a given total VFA production rate by the total volume of forestomach fluid found in the individual animal the total in vivo production rate could be obtained. From this the total $24 \mathrm{~h}$ production of VFA could be calculated, and assuming that the total production of VFA in the forestomach is absorbed, we could also calculate the contribution of VFA to the total energy budget. Energy available through the VFA pool was calculated using energy values of 874, 1534 and $2190 \mathrm{~kJ} / \mathrm{mol}$ for acetic acid, propionic acid and butyric acid respectively (calculated from Blaxter, 1962).

\section{$p H$ and temperature}

The $\mathrm{pH}$ was recorded (Olsen et al. 1994b) in the filtered forestomach fluid each time subsamples for VFA determination were collected. By extrapolating the calculated regression lines for the changes in $\mathrm{pH}$ to zero the $\mathrm{pH}$ at the time of death could be calculated, and the slope of the line gives the change in $\mathrm{pH}$ per unit time. The temperature in the forestomach samples was 26.7 (SD 1.20) ${ }^{\circ}$ at the first sampling and increased slightly to 29.0 (SD 1.41$)^{\circ}$ at the final sampling.

\section{GLC analysis}

Acidic fermentation products (VFA and lactate) were determined by GLC (Chrompack CP 9000 ; Chrompack, Bergen op Zoom, Holland). The diluted sample was homogenized. An internal standard (IS) solution, 2-ethyl butyric acid $(100 \mu \mathrm{l})$, was added to $1 \mathrm{ml}$ of the homogenized sample together with $2 \mathrm{ml}$ diethyl ether and $0.5 \mathrm{ml} 12 \mathrm{M}-\mathrm{HCl}$, and mixed for $1 \mathrm{~min}$. The ether phase was removed, and the sample was once more extracted using $1 \mathrm{ml}$ diethyl ether. $N$-tert-butyldimethylsilyl- $N$-methyltrifluoroacetamide (MTBSTFA; $100 \mu$ ) was added to the combined ether extract in a test tube. The tube was sealed and the acids derivatised by heating for $20 \mathrm{~min}$ at $80^{\circ}$. The samples were kept at room temperature overnight, before injecting $0.5 \mu \mathrm{l}$ onto the gas chromatograph which was fitted with a CPSIL 8 CB column (Chrompack no. $7452,30 \mathrm{~m}, 0.25 \mathrm{~mm}$ ID) containing a $0.25 \mu \mathrm{m}$ film of silica gel. The carrier gas used was $\mathrm{H}_{2}$, velocity $45 \mathrm{~cm} / \mathrm{s}$, and the injection was not split $(60 \mathrm{~s})$. Injector temperature was $250^{\circ}$ and detector temperature $270^{\circ}$.

\section{Chemical composition of the forestomach contents}

The prey items found in the forestomach were identified according to standard external criteria (Haug et al. 1995). Forestomach contents for chemical analysis were collected and frozen immediately at $-20^{\circ}$. The percentage DM was determined after preheating for $24 \mathrm{~h}$ 
Table 1. Chemical composition of the forestomach contents of five minke whales (Balaenoptera acutorostrata)

\begin{tabular}{|c|c|c|c|c|c|c|c|c|}
\hline \multirow[b]{2}{*}{$\begin{array}{l}\text { Whale } \\
\text { no. }\end{array}$} & \multirow[b]{2}{*}{ Prey* ( $\%$ of biomass) } & \multirow[b]{2}{*}{$\begin{array}{c}\text { DM } \\
(\mathrm{g} / \mathrm{kg} \text { fresh } w t)\end{array}$} & \multicolumn{6}{|c|}{$\mathrm{g} / \mathrm{kg} \mathrm{DM}$} \\
\hline & & & Ash & $\begin{array}{l}\text { Crude } \\
\text { protein }\end{array}$ & $\begin{array}{c}\text { True } \\
\text { protein }\end{array}$ & Lipids & $\mathrm{NH}_{4}-\mathrm{N}$ & $\begin{array}{l}\text { Water-soluble } \\
\text { carbohydrates }\end{array}$ \\
\hline S6 & Capelin (86), Crustaceans (14) & 91 & 209 & 584 & 232 & 209 & $15 \cdot 4$ & $48 \cdot 4$ \\
\hline S7 & Crustaceans (92), Capelin (8) & 94 & 117 & 652 & 139 & 367 & $42 \cdot 6$ & $57 \cdot 4$ \\
\hline S8 & Capelin (100) & 137 & 80 & 726 & 320 & 303 & $28 \cdot 5$ & $47 \cdot 4$ \\
\hline S11 & Capelin (100) & 180 & 72 & 684 & 248 & 403 & $19 \cdot 4$ & $48 \cdot 9$ \\
\hline S14 & Capelin (86), Crustaceans (14) & 98 & 92 & 606 & 85 & 367 & $20 \cdot 4$ & $64 \cdot 3$ \\
\hline
\end{tabular}

* Data from Haug et al. (1995).

at $80^{\circ}$ and then heating at $103-105^{\circ}$ for $4 \mathrm{~h}$. The forestomach contents were ashed at $550^{\circ}$ for $12 \mathrm{~h}$. $\mathrm{N}$ content was determined using the Kjeldahl method (Horwitz, 1980) and converted to crude protein by multiplication by $6 \cdot 25$. True protein was determined according to the method of Barnstein-Stutzer (Horwitz, 1980), by dissolving the forestomach sample in distilled water in a boiling water bath, and precipitating the protein by adding $\mathrm{AlK}\left(\mathrm{SO}_{4}\right)_{2} .12 \mathrm{H}_{2} \mathrm{O}, \mathrm{CuSO}_{4}$ and $\mathrm{NaOH}$, before filtering and finally by use of the Kjeldahl method. To evaluate the lipid content the forestomach contents were mixed with dried $\mathrm{Na}_{2} \mathrm{SO}_{4}$ to bind water, and the fat extracted by ethyl acetate (Losnegard et al. 1979). $\mathrm{NH}_{3}$ and other volatile $\mathrm{N}$-compounds $\left(\mathrm{NH}_{4}-\mathrm{N}\right)$ were liberated from an aqueous extract of the forestomach contents by addition of $\mathrm{MgO}$ to give a $\mathrm{pH}$ of $>7.5$ when boiled, the distillate was allowed to react with $\mathrm{H}_{2} \mathrm{SO}_{4}$, and excess acid was titrated with $\mathrm{NaOH}$ solution (Horwitz, 1980). To determine the concentration of water-soluble carbohydrates, forestomach contents were extracted with water, filtered, hydrolysed with $\mathrm{H}_{2} \mathrm{SO}_{4}$ in a water bath, neutralized with $\mathrm{NaOH}$ (Smith \& Grotelueschen, 1966), and deproteinized with ZnS/ $\mathrm{Ba}(\mathrm{OH})_{2}$, and the carbohydrate content assayed using the ferricyanide method (Furuholmen et al. 1964).

\section{Statistical analysis}

Concentrations of the main VFA (acetate, propionate and butyrate) and $\mathrm{pH}$ at the time the animals were shot, the production rates of VFA and the change in $\mathrm{pH}$ were calculated with $99 \%$ confidence intervals by regression lines analyses.

\section{RESULTS}

All animals had been eating capelin (Mallotus villosus), or a mixture of capelin and crustaceans (Thysanoessa sp.) (Table 1) (Haug et al. 1995). Crude protein, lipids and $\mathrm{NH}_{3}$ were found to constitute 650 (SD 58), 330 (SD 77) and 25.3 (SD 10.8) g/ kg DM of the forestomach contents respectively. The water-soluble carbohydrates constituted $53 \cdot 3$ (SD $7 \cdot 3) \mathrm{g} / \mathrm{kg} \mathrm{DM}$ of the forestomach contents (Table 1).

The main VFA and lactate were recorded in the forestomach fluid of all the minke whales (Fig. 1). We were, however, unable to identify several components which had retention times at approximately 4.95 (peak z), 6.08 (peak x) and 7.02 (peak y) on the GLC profiles (Fig. 1). In addition to the main VFA, isobutyrate $(1.22$ (SD 0.47$) \mathrm{mm}$ ), isovalerate $(2 \cdot 27$ (SD 


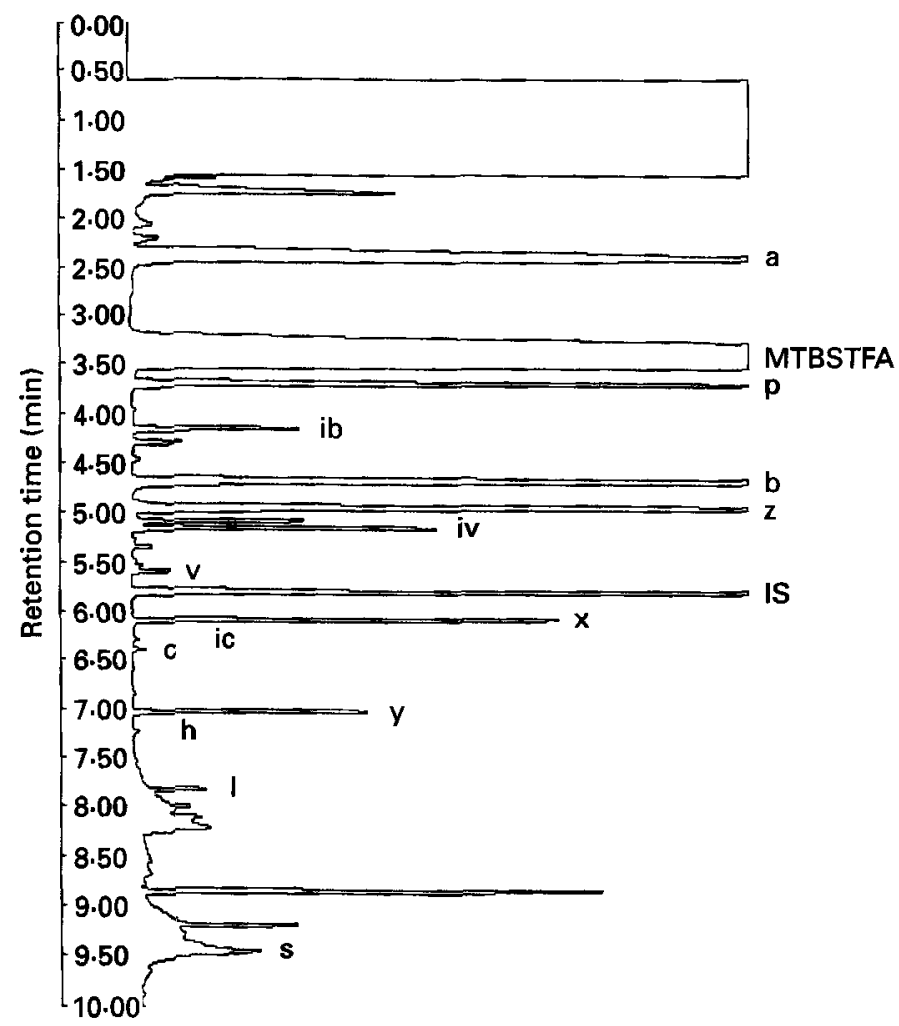

Fig. 1. Gas chromatography profile of fermentation products from forestomach contents of a minke whale (Balaenoptera acutorostrata; S8) which had been eating capelin (Mallotus villosus). Peaks: a, acetate; MTBSTFA, reagents; $p$, propionate; $\mathrm{ib}$, isobutyrate; $\mathrm{b}$, butyrate; $\mathrm{z}$, unknown, retention time approximately 4.95 ; iv, isovalerate; $v$, valerate; IS, internal standard; $x$, unknown, retention time 6.08 ; ic, isocaproate; caproate; $y$, unknown, retention time $7 \cdot 02 ; \mathrm{h}$, heptanoate; 1 , lactate and $\mathrm{s}$, succinate.

$0.61) \mathrm{mM}$ ), valerate $(0.14(\mathrm{SD} 0.03) \mathrm{mM})$, isocaproate $(0.06$ (SD 0.04) $\mathrm{mM})$, caproate $(0.10$ (SD $0.06) \mathrm{mM})$, heptanoate $(0.022(\mathrm{SD} 0.004) \mathrm{mM})$ and lactate $(7.51$ (SD 5.84) $\mathrm{mM}$ ) were present in the initial sample of forestomach fluid. We were not able to detect VFA in the blood samples.

The regression line plots, including data for each individual regression curve, for the VFA as a function of time are presented in Fig. 2. Calculations of regression lines for VFA as a function of time gave correlation coefficients (range) of 0.924-0.999. Concentration, pool size and production rates of the most important VFA (acetate, propionate and butyrate) in the forestomach fluid of minke whales are presented in Table 2 . Forestomach VFA concentration ranged from 13.2 to $68.5 \mathrm{mmol} / \mathrm{l}$, the VFA pool size ranged from 72.8 to $638.1 \mathrm{mmol}$, and the VFA-production rate was maximally $1695 \mathrm{mmol} / \mathrm{h}$ (Table 3 ). Acetate contributed 70.05 (SD 11.05) \% to the total VFA concentration, while propionate and butyrate contributed 10.35 (SD 4.86) and 19.60 (SD 6.62) \% respectively. The energy contents of the VFA pool ranged from $99.3 \mathrm{~kJ}\left(0.169 \mathrm{~kJ} / \mathrm{kg}\right.$ live weight (W) $\left.{ }^{0.75}\right)$ to $712.6 \mathrm{~kJ}\left(2 \cdot 107 \mathrm{~kJ} / \mathrm{kg} \mathrm{W}^{0.75}\right.$; Table 2$)$. Daily production of VFA represented maximally $107.4 \mathrm{~kJ} / \mathrm{kg} \mathrm{W}^{0.75}$ (Table 2). Calculations of regression lines for $\mathrm{pH}$ as a function of time gave correlation coefficients (range) of $0 \cdot 753-0 \cdot 972$. The calculated mean forestomach $\mathrm{pH}$ was 5.83 (SD 0.41), and increased 0.21 (SD 0.12) $\mathrm{pH}$ units/h (Table 3). 

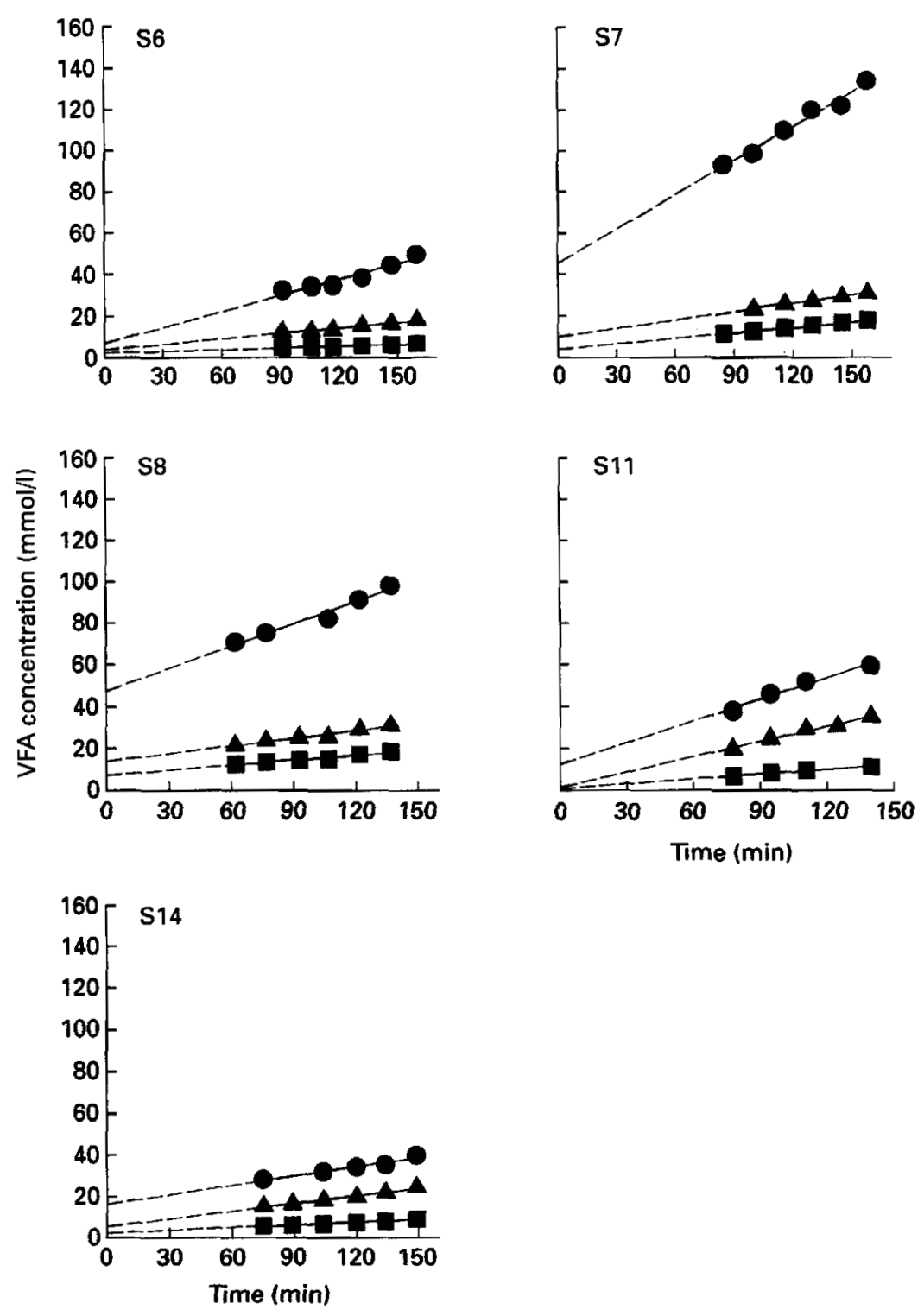

Fig. 2. For legend see opposite.

\section{DISCUSSION}

The concentration and composition of VFA in the minke whale forestomach (Table 2) are comparable with those found in the rumen fluid of domestic ruminants eating a poorquality forage (Hungate, 1966). Habitat similarities like temperature, $\mathrm{pH}$ and anaerobic conditions are reflected in that the forestomach is populated by anaerobic bacterial genera which also occur in the rumen of ruminants (Olsen et al. 1994a). In ruminants the VFA concentration is determined by food quality and quantity (Hungate, 1966). White \& Staaland (1983) used ruminal VFA production as an indicator of change in forage quality 
in the high Arctic Svalbard reindeer (Rangifer tarandus platyrhynchus). Orpin et al. (1985) also confirmed that the seasonal changes in pasture strongly influenced the composition of the rumen bacterial population. The chemical composition of plants eaten by herbivore ruminants differs considerably from that of prey items, like krill and fish, consumed by minke whales. The difference in fermentation substrate may be reflected in that several unknown VFA were demonstrated in the minke whale forestomach fluid in addition to acetate, propionate and butyrate (Fig. 1). These unknown VFA may be branched-chain isomers produced when such unusual substrates are used for forestomach fermentation. The chemical analyses of the forestomach contents confirmed that proteins and lipids constituted a high percentage of the DM (Table 1). These are all substrates that may be degraded by fermentation. The presence of branched chain VFA indicates occurrence of protein fermentation (McInerney, 1988). The large variations in VFA concentrations found between individual animals examined (Table 2) could be related to individual variations in food intake and food quality. These indicate that minke whales are able to adapt to different diets, which is also reflected in the range of VFA production rates found in different animals (Table 2). Observations of VFA in the forestomach of large baleen whales, like the grey, bowhead and fin while, indicated very high VFA concentrations (Herwig et al. 1984; Herwig \& Staley, 1986) compared with those found in minke whales (Table 2). This could be explained by the fact that Herwig et al. (1984) and Herwig \& Staley (1986) were only able to measure the VFA concentration $72 \mathrm{~h}$ after death.

In domesticated ruminants fed on a high-quality diet the rumen $\mathrm{pH}$ is usually between 5.5 and 6.7 (Hungate, 1966). The $\mathrm{pH}$ measured in the forestomach fluid (Table 3) of minke whales was comparable with these $\mathrm{pH}$ values. The rumen $\mathrm{pH}$ decreases when the VFA concentration in the rumen fluid increases (Hungate, 1966). In minke whales, however, the $\mathrm{pH}$ increased (Table 3) in parallel with an increase in the VFA concentration (Fig. 2). This finding could be explained by the buffering capacity of the high concentration of proteins

Fig. 2. Regression lines plot for the concentrations of the main volatile fatty acids (VFA): (O), acetate; (A), butyrate and $(\square)$, propionate, in forestomach fluid from the minke whale (Balaenoptera acutorostrata) ( $n$ 5) as a function of time. Values for the individual regression equations are given in the Table below.

\begin{tabular}{|c|c|c|c|}
\hline \multirow[b]{2}{*}{ Whale no. } & \multirow[b]{2}{*}{ VFA } & \multicolumn{2}{|c|}{$\begin{array}{l}\text { Regression equation: } \\
\qquad y=a x+b\end{array}$} \\
\hline & & $a$ & $b$ \\
\hline S6 & $\begin{array}{l}\text { Acetate } \\
\text { Butyrate } \\
\text { Proprionate }\end{array}$ & $\begin{array}{l}0.252 \\
0.087 \\
0.026\end{array}$ & $\begin{array}{l}7.095 \\
3.697 \\
2.445\end{array}$ \\
\hline S7 & $\begin{array}{l}\text { Acetate } \\
\text { Butyrate } \\
\text { Proprionate }\end{array}$ & $\begin{array}{l}0.559 \\
0.135 \\
0.092\end{array}$ & $\begin{array}{r}44.923 \\
10.044 \\
3.830\end{array}$ \\
\hline S8 & $\begin{array}{l}\text { Acetate } \\
\text { Butyrate } \\
\text { Proprionate }\end{array}$ & $\begin{array}{l}0 \cdot 357 \\
0 \cdot 121 \\
0 \cdot 078\end{array}$ & $\begin{array}{r}47 \cdot 341 \\
13 \cdot 854 \\
7 \cdot 263\end{array}$ \\
\hline $\mathbf{S} 11$ & $\begin{array}{l}\text { Acetate } \\
\text { Butyrate } \\
\text { Proprionate }\end{array}$ & $\begin{array}{l}0 \cdot 344 \\
0 \cdot 242 \\
0 \cdot 077\end{array}$ & $\begin{array}{r}12.456 \\
1.514 \\
1.009\end{array}$ \\
\hline S14 & $\begin{array}{l}\text { Acetate } \\
\text { Butyrate } \\
\text { Proprionate }\end{array}$ & $\begin{array}{l}0 \cdot 149 \\
0 \cdot 124 \\
0 \cdot 045\end{array}$ & $\begin{array}{r}16 \cdot 594 \\
5 \cdot 527 \\
2 \cdot 306\end{array}$ \\
\hline
\end{tabular}




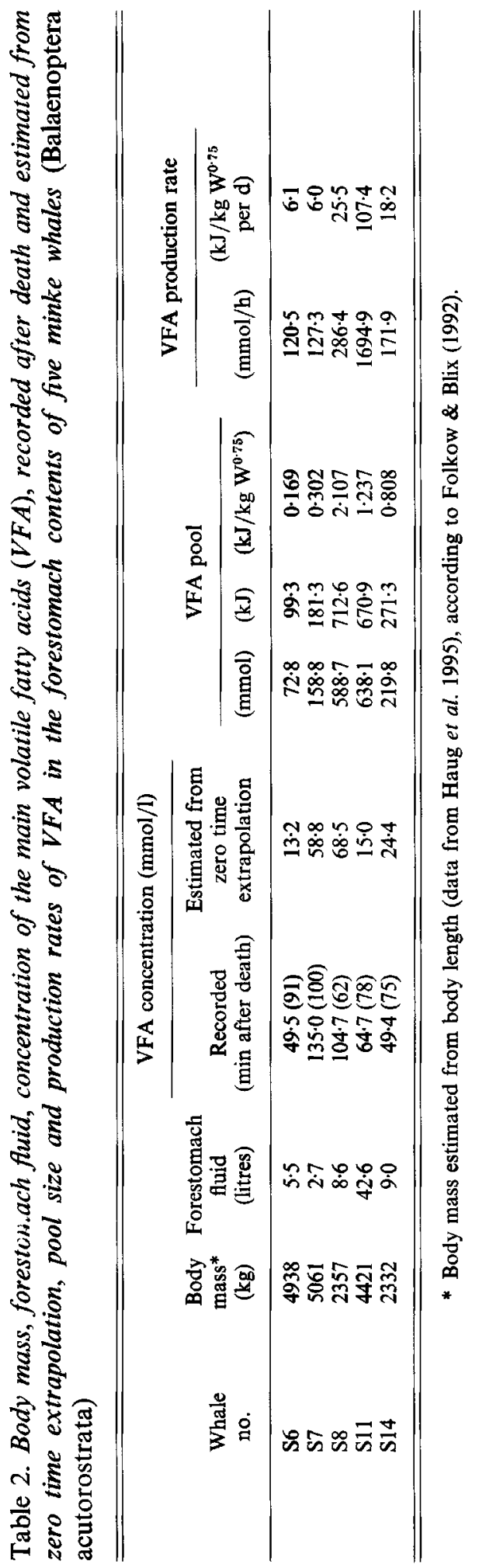


Table 3. Forestomach $\mathrm{pH}$, recorded after death and estimated from zero time extrapolation, and post-mortem changes in forestomach $\mathrm{pH}$ in five minke whales (Balaenoptera acutorostrata)

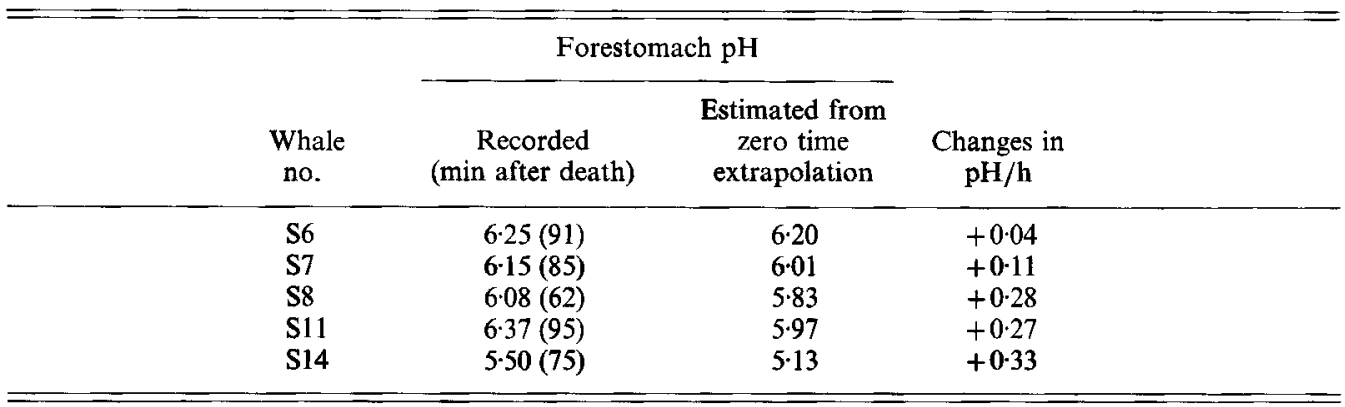

and $\mathrm{NH}_{3}$ in the forestomach contents (Table 1). Bacterial breakdown of protein could increase the concentration of $\mathrm{NH}_{3}$ and hence neutralize acids produced.

The average energy expenditure in minke whales is estimated to be approximately $635 \mathrm{~kJ} / \mathrm{kg} \mathrm{W}^{0.75}$ per d (calculated for an average-sized $(4000 \mathrm{~kg}$ ) whale, from Blix \& Folkow, 1995). In most of the animals examined the energy passing through the VFA pool contributed very little $(0 \cdot 9-4.0 \%)$ to the total energy expenditure, due to small forestomach volumes (Table 3) with low DM contents (Table 1). In one animal, however, the forestomach fluid measured 42.6 litres (Table 3), and in this animal the energy passing through the VFA pool contributed $16.9 \%$ of the daily total energy expenditure, assuming that all the VFA are absorbed from the forestomach. The in situ volume of the forestomach contents in minke whales is known to vary considerably, and volumes from 5 to 80 litres have been observed, representing 0.11 to $1 \cdot 15 \%$ of the body mass (Olsen et al. 1994b). In ruminants like the Svalbard reindeer the rumen reticulum content represents $16 \%$ of the body mass with a mean daily VFA production rate of $840 \mathrm{~kJ} / \mathrm{kg} \mathrm{W}^{\mathbf{0 . 7 5}}$ (White \& Staaland, 1983) compared with maximally $107.5 \mathrm{~kJ} / \mathrm{kg} \mathrm{W}^{0.75}$ per $\mathrm{d}$ in minke whales (Table 2). Bacterial fermentation in the forestomach of minke whales is therefore thought to vary, depending on the volume and quality of digesta. This influences fermentation rate and concentration of VFA, but the contribution of VFA to the daily energy requirement in minke whales seems to be of less importance than in ruminants. Weston \& Hogan (1968) observed a maximal production rate of VFA of $7775 \mathrm{~kJ} / \mathrm{d}$ in sheep $(40-47 \mathrm{~kg}$ ) with 5 litres of rumen fluid. Assuming the same production rate of VFA in a minke whale $(6900 \mathrm{~kg})$ with a forestomach containing 65 litres of forestomach fluid (Olsen et al. 1994b), VFA produced by bacterial fermentation would contribute $101075 \mathrm{~kJ} / \mathrm{d}$ and hence cover only $21 \%$ of the daily energy expenditure.

Digestion based on bacterial fermentation is accomplished by loss of energy through $\mathrm{CH}_{4}$, lost in eructation, and $\mathrm{NH}_{3}$, which was found to constitute from 15.4 to $42.6 \mathrm{~g} / \mathrm{kg}$ DM of the forestomach contents in minke whales (Table 1). Even though $70 \%$ of the DM of the substrate disappeared into solution by bacterial degradation in the forestomach fluid (Nordøy et al. 1993), our studies indicate that the forestomach microbial fermentation contributes little to the energy requirement from prey in minke whales. The compartmentalized stomach probably increases passage time to the stomach and hence time available for microbial and enzymic digestion. It is suggested that the relatively small size of the forestomach in minke whales reflects the carnivorous diet, but does not necessarily indicate any reduced importance of the forestomach microbial digestion (Olsen et al. $1994 b$; Mathiesen et al. 1995). 
We thank Tore Haug, Gjermund Bøe, Nils Erik Skavberg, Egil Ole Øen and the whaling crew on board $M / V$ 'Asbjorn Selsbane' for their co-operation and assistance in the field. The study was supported by The Roald Amundsen Centre for Arctic Research, Kellfrid and Helge Jakobsens Foundation at the University in Tromsø, and the Norwegian Research Council (grant no. 4001-408.007).

\section{REFERENCES}

Aagnes, T. H., Sørmo, W. \& Mathiesen, S. D. (1995). Ruminal microbial digestion in free-living, in captive lichenfed, and in starved reindeer (Rangifer tarandus tarandus) in winter. Applied and Environmental Microbiology 61, 583-591.

Allo, A. A., Oh, J. H., Longhurst, W. M. \& Connolly, G. E. (1973). VFA production in the digestive systems of deer and sheep. Journal of Wildlife Management 37, 202-211.

Annison, E. F. \& Armstrong, D. G. (1970). Volatile fatty acid metabolism and energy supply. In Physiology of Digestion and Metabolism in the Ruminant, pp. 422-437. Newcastle upon Tyne: Oriel Press.

Anonymous (1950). International Convention for the Regulation of Whaling. First Report of the International Commission of Whaling, Appendix I, pp. 9-14. London: International Commission on Whaling.

Blaxter, K. L. (1962). The Energy Metabolism in Ruminants. London: Hutchinson Scientific and Technical.

Blix, A. S. \& Folkow, L. P. (1995). Daily energy expenditure in free living minke whales. Acta Physiologica Scandinavica 153, 61-66.

Carroll, E. J. \& Hungate, R. E. (1954). The magnitude of the microbial fermentation in the bovine rumen. Applied Microbiology 2, 205-214.

Folkow, L. P. \& Blix, A. S. (1992). Metabolic rates of minke whales (Balaenoptera acutorostrata). Acta Physiologica Scandinavica 146, 141-150.

Furuholmen, A. M., Winefordner, J. D., Knapp, F. W. \& Dennison, R. A. (1964). The qualitative analysis of glucose and fructose in potatoes. Journal of Agricultural and Food Chemistry 12, 109-112.

Gasaway, W. C. \& Coady, J. W. (1974). Review of energy requirements and rumen fermentation in moose and other ruminants. Le Naturaliste Canadien 101, 227-262.

Haug, T., Gjøsæter, H., Lindstrøm, U. \& Nilssen, K. T. (1995). Diet and food availability for north-east Atlantic minke whales (Balaenoptera acutorosrata), during the summer of 1992. ICES Journal of Marine Science 52, $77-86$.

Herwig, R. P. \& Staley, J. T. (1986). Anaerobic bacteria from the digestive tract of North Atlantic fin whales (Balaenoptera physalus). FEMS Microbial Ecology 38, 361-371.

Herwig, R. P., Staley, J. T., Nerini, M. K. \& Braham, H. W. (1984). Baleen whales: preliminary evidence for forestomach microbial fermentation. Applied and Environmental Microbiology 47, 421-423.

Horwitz, W. (1980). Official Methods of Analysis of the Association of Analytical Chemists, 13th ed. Washington: AOAC.

Hungate. R. E. (1966). The Rumen and its Microbes. New York: Academic Press.

Hungate, R. E., Mah, R. A. \& Simesen, M. (1961). Rates of production of individual volatile fatty acids in the rumen of lactating cows. Applied Microbiology 9, 554-561.

Losnegard, N., Bøe, B. \& Larsen, T. (1979). Norwegian Directorate of Fisheries Report no. 1. Bergen, Norway: Norwegian Directorate of Fisheries. (In Norwegian).

McInerney, M. J. (1988). Anaerobic hydrolysis and fermentation of fats and proteins. In Biology of Anaerobic Microorganisms [A. J. B. Zehnder, editor]. New York: John Wiley \& Sons.

Mathiesen, S. D., Aagnes, T. H., Sørmo, W., Nordøy, E. S., Blix, A. S. \& Olsen, M. A. (1995). Digestive physiology of minke whales. In Marine Biology IV. Proceedings of an International Symposium on the Biology of Marine Mammals in the Northeast Atlantic, pp. 351-359 [A. S. Blix, L. Walløe \& Ø. Ulltang, editors]. Amsterdam: Elsevier Publisher B. V.

Nordøy, E. S. \& Blix, A. S. (1992). Diet of minke whales in the Northeastern Atlantic. Reports of the International Whaling Commission 42, 393-398.

Nordøy, E. S., Sørmo, W. \& Blix, A. S. (1993). In vitro digestibility of different prey species of minke whales (Balaenoptera acutorostrata). British Journal of Nutrition 70, 485-489.

Olsen, M. A., Aagnes, T. H. \& Mathiesen, S. D. (1994a). Digestion of herring by indigenous bacteria in the minke whale forestomach. Applied and Environmental Microbiology 60, 4445-4455.

Olsen, M. A., Nordøy, E. S., Blix, A. S. \& Mathiesen, S. D. (1994b). Functional anatomy of the gastrointestinal system of Northeastern Atlantic minke whales (Balaenoptera acutorostrata). Journal of Zoology 234, 55-74.

Orpin, C. G., Mathiesen, S. D., Greenwood, Y. \& Blix, A. S. (1985). Seasonal changes in the ruminal microflora of the high-arctic Svalbard reindeer (Rangifer tarandus platyrhynchus). Applied and Environmental Microbiology 50, $144-151$.

Smith, D. \& Grotelueschen, R. D. (1966). Carbohydrates in grasses. I. Sugar and fructosan composition of the stem bases of several northern-adapted grasses at seed maturity. Crop Science 6, 263-266.

Stevens, C. E. (1973). Transport across rumen epithelium. In Transport Mechanisms in Epithelia, pp. 404-426 [H. H. Ussing and N. A. Thorn, editors]. Copenhagen: Munksgaard. 
Stewart, W. E., Stewart, D. G. \& Schultz, L. H. (1958). Rates of volatile fatty acid production in the bovine rumen. Journal of Animal Science 17, 723-736.

Tilley, J. M. A. \& Terry, R. A. (1963). A two-stage technique for the in vitro digestion of forage crops. Journal of the British Grassland Society 18, 104-111.

van Hoven, W., Prins, R. A. \& Lankhorst, A. (1981). Fermentative digestion in the African elephant. South African Journal of Wildlife Research 11, 78-86.

Wardrop, I. D. \& Coombe, J. B. (1960). The post-natal growth of the visceral organs of the lamb. Journal of Agricultural Science 54, 140-143.

Weston, R. H. \& Hogan, J. P. (1968). The digestion of pasture plants by sheep. I. Ruminal production of volatile fatty acids by sheep offered diets of ryegrass and forage oats. Australian Journal of Agricultural Research 19 , 419-432.

White, R. G. \& Staaland, H. (1983). Ruminal volatile fatty acid production as an indicator of forage quality in Svalbard reindeer. Acta Zoologica Fennica 175, 61-63. 